Dialectologia. Special issue, $\boldsymbol{V}$ (2015), 53-80.

ISSN: 2013-2247

Received 23 April 2015.

Accepted 8 September 2015.

\title{
CAUSATIVE AND PERCEPTION CONSTRUCTIONS IN EUROPEAN PORTUGUESE: THE DIALECTAL DATA ${ }^{1}$
}

\author{
Sandra PEREIRA \\ Centro de Linguística da Universidade de Lisboa \\ Faculdade de Letras da Universidade de Lisboa \\ spereira@clul.ul.pt
}

\section{Abstract}

This paper deals with the infinitival complements of the causative and perception verbs in European Portuguese (EP) dialects. It is based on the corpus CORDIAL-SIN (Syntax-Oriented Corpus of Portuguese Dialects - cf. http://www.clul.ul.pt/en/researcher/225-description-cordial-sin-syntaxoriented-corpus-of-portuguese-dialects) and its main goal is to describe these constructions and contrast them with the ones described for the standard EP. On one hand, the constructions identified in the standard variety, such as 1) Inflected Infinitive, 2) Exceptional Case Marking (ECM), 3) Faire-Inf and 4) Gerundial Infinitive (only for perception verbs), can be found in Portuguese dialects; by contrast, other (dialectal) non identified constructions occur in the dialectal corpus.

Additionally, it is also our aim to map these different constructions in an attempt to detect some geolinguistic variation to identify syntactic areas.

In what concerns the standard variety of EP, the ECM construction seems to be more common. This trend however is not confirmed by this dialectal data. Surprisingly, ECM constructions (as well as the Inflected Infinitive ones) do not show up very often and are not spread over the whole territory. Given the small amount of available data, namely for ECM construction, a parallelism between some EP varieties and other Romance languages can be suggested. In fact, it seems that this construction is not accessible in some EP varieties like it happens in the other Romance languages.

\footnotetext{
${ }^{1}$ This work was developed under a PhD research grant (cf. Pereira 2012) funded by Fundação para a Ciência e Tecnologia (SFRH/BD/27648/2006).
} 
In contrast, the Faire-Inf construction, which is the most frequent construction in the corpus and it is spread over the continental territory, is not found on the data from Madeira.

\section{Keywords}

causative constructions, perception constructions, syntactic variation, geolinguistic distribution, European Portuguese dialects

\section{CONSTRUÇõES CAUSATIVAS E PERCETIVAS EM PORTUGUÊS EUROPEU: DADOS DIALETAIS}

\section{Resumo}

Este trabalho explora os complementos infinitivos dos verbos causativos e percetivos nos dialetos do português europeu (PE). Tem como suporte empírico o corpus CORDIAL-SIN (SyntaxOriented Corpus of Portuguese Dialects - cf. http://www.clul.ul.pt/en/researcher/225-descriptioncordial-sin-syntax-oriented-corpus-of-portuguese-dialects) e o seu principal objetivo é descrever estas construções e contrastá-las com as construções descritas para o PE padrão. Por um lado, as construções identificadas para a variedade padrão, como 1) construção de Infinitivo Flexionado, 2) Marcação Excecional de Caso (ECM), 3) Faire-inf e 4) Infinitivo Gerundivo (no caso dos verbos percetivos), estão atestadas nos dialetos portugueses; por outro lado, há outras construções (dialetais) não identificadas que ocorrem no corpus dialetal.

Paralelamente, um outro objetivo é mapear estas construções na tentativa de detetar alguma variação geolinguística com vista à identificação de áreas sintáticas.

No que se refere à variedade padrão do $\mathrm{PE}$, a construção de ECM parece ser a mais comum. No entanto, esta tendência não é confirmada pelos dados dialetais. De facto, a construção ECM (bem como a de Infinitivo Flexionado) não é muito frequente nem aparece muito disseminada pelo território português. A pouca quantidade de dados, designadamente para a construção de ECM, permite sugerir um paralelismo entre as variedades do PE e outras línguas românicas, na medida em que esta construção não parece estar disponível para alguns dialetos do PE, tal como acontece com as outras línguas românicas.

Surpreendentemente, a construção Faire-inf, que é a mais frequente no corpus e a mais espalhada por todo o território continental, não se encontra atestada nos dados recolhidos na Madeira.

\section{Palabras clave}

construções causativas, construções percetivas, variação sintática, distribuição geolinguística, dialetos do potuguês europeu 


\section{Introduction}

The goal of this paper is to describe the behaviour of causative and perception verbs with non-finite complements in dialectal European Portuguese (henceforth EP). In particular, we want to verify whether the constructions identified for standard EP (e.g. Gonçalves 2001) also occur in the dialectal corpus CORDIAL-SIN (Syntax-oriented corpus of Portuguese Dialects).

Furthermore, the distribution of dialectal data will be mapped in an attempt to detect some geolinguistic variation and to identify syntactic areas.

The paper is organized as follows: after this Introduction, in the second section, I will describe the corpus in which this work is based on. In the third section, I will provide a description of the causative and perception constructions with non-finite complements. The dialectal data will be described in section 4, regarding not only the constructions that occur in the corpus but also their distribution. Finally, in section $5 \mathrm{I}$ will present some concluding remarks.

\section{Corpus}

CORDIAL-SIN is an annotated dialectal corpus developed at the Centre of Linguistics of the University of Lisbon (CLUL). This corpus has more than six hundred thousand words (about 70 hours of recordings in 42 locations in Portuguese insular and continental territory). It is a compilation of excerpts of spontaneous and semidirected speech drawn from traditional geolinguistic fieldwork, since its source is the Dialectal Sound Archive at CLUL.

CORDIAL-SIN provides detailed Part-Of-Speech and syntactic annotation and it is completely available (http://www.clul.ul.pt/en/research-teams/411-cordial-corpus). This dialectal resource has significantly contributed to the studies of dialectal syntax of EP (cf. Martins 2000-). 


\section{Non-finite complements of causative and perception verbs in European Portuguese}

The constructions with causative verbs and infinitival complements present some particularities across the Romance languages, namely "the distribution of the thematic subject of the infinitive verb embedded under the causative, and the behavior of its arguments with respect to certain syntactic processes like cliticization and passivization" (cf. Guasti 2005). In EP, unlike other Romance languages, there are no clear asymmetries between causative and perception verbs, since they show structural similarities. Consensually, deixar (to let), fazer (to make) e mandar (to order) are considered the typical causative verbs and ouvir (to hear), sentir (to feel) e ver (to see) the perception ones.

Gonçalves (1999, 2001), Gonçalves \& Duarte (2001) and Duarte \& Gonçalves (2002) identified different structures with these verbs, namely: i) inflected infinitive construction; ii) Exceptional Case Marking construction (ECM); iii) Faire-Infinitive construction (cf. Kayne 1975); and, only with perception verbs, iv) Prepositional Infinitival construction (cf. Raposo 1989). These constructions will be described in the next sections.

\subsection{Inflected Infinitive Construction}

In the Inflected Infinitive construction the subject of the infinitival construction occurs between the finite verb and the embedded one (cf. (1)-(2) and it is a nominative subject whose case is assigned in the infinitival domain (cf. (1b.)). The traces of person and number of this subject are also marked in the infinitival form, as it is shown by the contrast between examples b) and c).
a. A mãe mandou os filhos comerem a sopa.
The mother ordered the children to.eat.3PL the soup
b. A mãe mandou eles comerem a sopa. 
Dialectologia. Special issue, $\mathbf{V}$ (2015), 53-80.

ISSN: 2013-2247

The mother ordered they.NOM.to.eat.3PL the soup

c. *Amãe mandou eles comer a sopa.

The mother ordered they.NOM.to.eat.3SG the soup

'The mother made the children eat the soup.'

(2)

a. A mãe viu os filhos comerema sopa.

The mother saw the children to.eat.3PL the soup

b. A mãe viu eles comerema sopa.

The mother saw they.NOM.to.eat.3PL the soup

c. * Amãe viueles comer a sopa.

The mother saw they.NOM.to.eat.3SG the soup

'The mother saw the children eating the soup.'

In this construction, the embedded domain reveals some syntactic autonomy as it admits sentential negation and it allows the presence of complement clitics:

a. A mãe mandou os filhos não comerem a sopa.

The mother ordered the children NOT to.eat.3PL the soup

'The mother made the children not eat the soup.'

b. A mãe mandou os filhos comerem-na.

The mother ordered the children eat.3PL-it.ACC

'The mother made the children eat it.'

(4)

a. A mãe viuos filhos não comerema sopa.

The mother saw the children NOT to.eat.3PL the soup

'The mother saw the children not eating the soup.'

b. A mãe viu os filhos comerem-na.

The mother saw the children eat.3PL-it.ACC

'The mother saw the children eating it.'

\subsection{Exceptional Case Marking Construction}

The ECM construction in EP can occur not only with perception verbs but also with causative verbs, unlike other Romance languages (cf. Guasti 2005). The typical 
order is the same as the English causatives and the infinitive is non-inflected. ${ }^{2}$ As it is shown by the examples (5)-(8), the subject of the infinitival construction occurs between both verbs and the case (accusative) is checked in the finite domain; if the subject is a pronoun, there is always clitic climbing. Furthermore, the infinitival verb does not display inflection.

(5)
a. $A \quad m \tilde{a}$
mandou os filhos
comer
sopa.

The mother ordered the children to.eat the soup

b. A mãe mandou-os comera sopa.

The mother ordered-them.ACC. to.eat the soup

c. *A mãe mandou-os comerema sopa.

The mother ordered-them.ACC. to.eat.3PL the soup

'The mother made the children eat the soup.'

(6) a. A mãe viuos filhos comera sopa.

The mother saw the children to.eat the soup

b. A mãe viu-os comer a sopa.

The mother saw-them.ACC. to.eat the soup

c. ${ }^{*} A$ mãe viu-os comerem a sopa.

The mother saw-them.ACC. to.eat.3PL the soup

'The mother saw the children eating the soup.'

In these structures, the infinitival domain expresses some syntactic autonomy to the extent that sentential negation is possible and the clitic complements are allowed:

(7) a. A mãe mandou os filhos não comera sopa.

The mother ordered the children NOT to.eat the soup

'The mother made the children not eat the soup.'

\footnotetext{
${ }^{2}$ There are some cases of ECM constructions where infinitive is apparently inflected since it does not assign nominative case:

i) $\mathrm{Vi}$ saírem no carrito dele e vi-os

Saw-them.ACC to.leave.3PL in.the little.car of.heand saw-them.ACC

quando chegaram.

when arrived

'I saw them leave in their little car and saw them again when they returned.'

(Newspaper Público (apud Martins forthcoming)

Please see, Hornstein, Martins \& Nunes (2006, 2008), Bossaglia (2013) and Martins (forthcoming).
} 
Dialectologia. Special issue, $\mathbf{V}$ (2015), 53-80.

ISSN: 2013-2247

b. A mãe mandou os filhos comê-la.

The mother ordered the children to.eat-it.ACC

'The mother made the children eat it.'

(8) a. $A$ mãe viu os filhos não comera sopa.

The mother saw the children NOT to.eat the soup

'The mother saw the children not eating the soup.'

b. A mãe viu os filhos comê-la.

The mother saw the children to.eat-it.ACC

'The mother saw the children eating it.'

Having in mind these two constructions, the Inflected Infinitive construction and the ECM construction, there is structural ambiguity between them, under some circumstances. In particular, if the subject of the embedded domain is a singular noun phrase, it is not possible to know which construction is involved. In fact, due to the lack of inflection in third singular person verbal form and because the case is not morphologically marked in noun phrases, sentences like (9a) and (10a) are ambiguous. This ambiguity is not present when the subject is a pronoun: if the pronoun is nominative, it is the Inflected Infinitive construction (cf. (9b) and (10b)); if the pronoun is accusative, the construction involved is the ECM (as is (9c) and (10c)).

(9) a. mãe mandou o filho comer The mother ordered the child.NOM/ACCto.eat.3SG/ $\varnothing$

a sopa.

the soup

'The mother made the child eat the soup.' (Infl. Inf. / ECM)

b. A mãe mandou ele comer a sopa.

The mother ordered him.NOM. to.eat.3SG the soup

'The mother made him eat the soup.' (Infl. Inf.)

c. A mãe mandou-o comer a sopa.

The mother ordered-him.ACC. to.eat $\varnothing$ the soup

'The mother made him eat the soup.'

(ECM) 


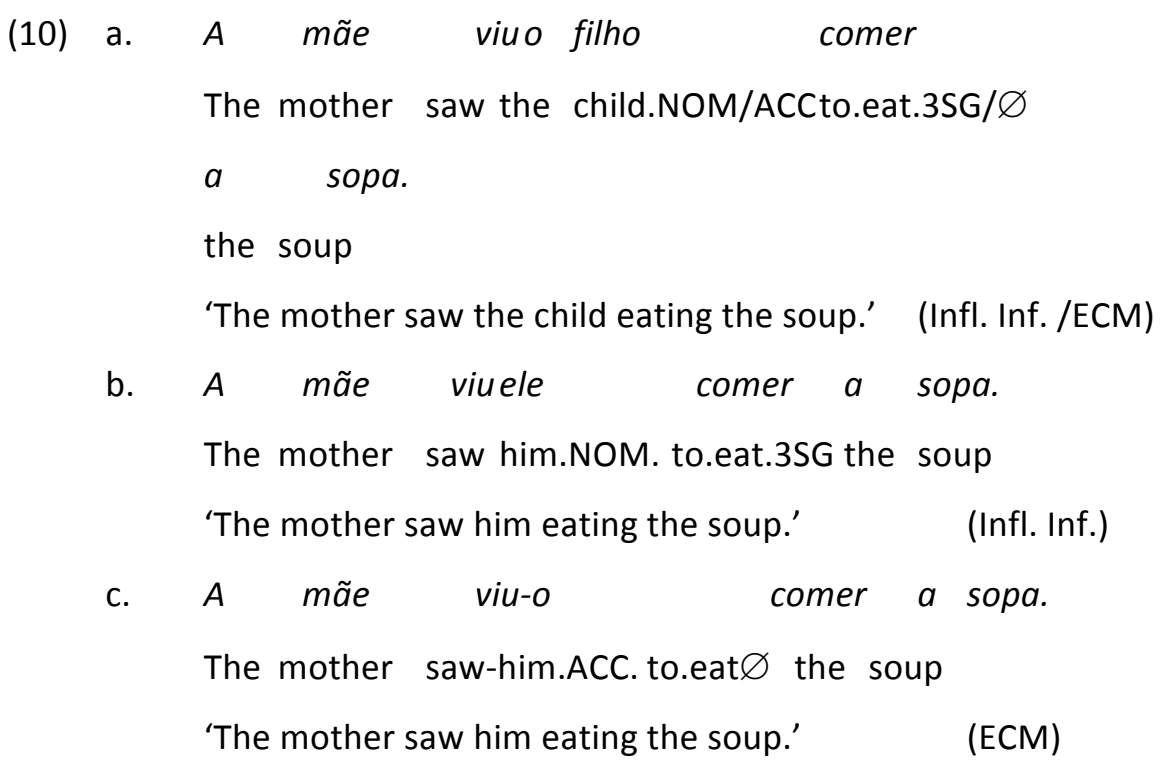

\subsection{Faire-Infinitive Construction}

Equally important is the construction that involves a complex predicate. The thematic subject of the infinitive verb occurs after both verbs. It is claimed, for instance by Gonçalves (2000), that, in this particular situation, this subject behaves like an object. It is a noun phrase if the verb has only one argument (cf. 11) and (13)) and it is a prepositional phrase when the verb has more than one argument (cf. (12) and (14)). Depending on that, the case assigned to the noun phrase is the accusative (cf. (11b) and (13b)) while the prepositional phrase gets dative case (cf. (12b) and (14b)). This is clearly demonstrated when it comes to pronouns, which morphologically manifest their case. Whenever it is a pronoun, clitic climbing is obligatory.

(11) a. $A$ mãe fez sorrir as pessoas.

The mother made to.smile the people

'The mother made people smile.'

b. $\quad$ mãe fê-las sorrir.

The mother made-them.ACC to.smile

'The mother made them smile.'

(12) a. A mãe mandou comera sopa ao filho.

The mother ordered to.eat the soup to.thechild

'The mother made the child eat the soup.' 
Dialectologia. Special issue, V (2015), 53-80.

ISSN: 2013-2247

b. A mãe mandou-lhe comer a sopa.

The mother ordered-him.DAT to.eat the soup

'The mother made him eat the soup.'

(13) a.

A mãe viu sorrir as pessoas.

The mother saw to.smile the people

'The mother saw people smiling.'

b. A mãe viu-as sorrir.

The mother saw-them.ACC to.smile

'The mother saw them smiling.'

(14) a. A mãe viu comera sopaao filho.

The mother saw to.eat the soup to.thechild

'The mother saw the child eating the soup.'

b. ?/*Amãe viu-lhe comera sopa.

The mother saw-him.DAT to.eat the soup

'The mother made saw him eating the soup.'

Most speakers of standard EP hardly accept the example (14b). It seems to exist a difference between causative verbs and perception ones: the latter do not permit that the thematic subject of the infinitive clause be a dative pronoun (it is preferable to use an accusative pronoun, i.e., the ECM construction). ${ }^{3}$

As the previous examples also demonstrate, the infinitival form in this construction does not exhibit inflectional brands. Moreover, this domain is not syntactically autonomous and the sentential negation is prohibited as well as the clitic complements.

(15) a. *A mãe fez não sorrir as pessoas.

The mother made not to.smile the people

'The mother made people not smile.'

b. *A mãe mandou-lhe comê-la.

The mother ordered-him.DAT to.eat-it.ACC

'The mother made him eat it.'

\footnotetext{
${ }^{3}$ For more about the difference between causative and perception verbs in the formation of complex predicates, please see Duarte \& Gonçalves (2002: 166).
} 
(16) a. *A mãe viu não sorrir as pessoas.

The mother saw not to.smile the people

'The mother saw people not smiling.'

b. ?/*A mãe viu-lhe comê-la.

The mother saw-him.DAT to.eat-itACC

'The mother made saw him eating the soup.'

Additionally, in some cases there is structural ambiguity between ECM construction and the Faire-Infinitive one. It actually happens under two circumstances:

(i) If the verb has only one argument and the thematic subject of the embedded domain is an accusative pronoun:

(17) a. A mãe fê-las sorrir.

The mother made-them.ACC to.smile

'The mother made them smile.'

(ECM / FI)

b. A mãe fez as pessoas sorrir.

The mother made the people to.smile

'The mother made people smile.'

c. $\quad$ mãe fez sorrir as pessoas.

The mother made to.smile the people

'The mother made people smile.'

(18) a. A mãe viu-as sorrir.

The mother saw-them.ACC to.smile

'The mother saw them smiling.'

b. A mãe viu as pessoassorrir.

The mother saw the people to.smile

'The mother saw people smile.'

c. $A$ mãe viu sorrir as pessoas.

The mother saw to.smile the people

'The mother saw people smile.' 
Dialectologia. Special issue, $\mathbf{V}$ (2015), 53-80.

ISSN: 2013-2247

(ii) If this subject is a first or second person pronoun since these forms are the same for accusative and dative:

(19) A mãe mandou-me comera sopa.

The mother ordered-me.ACC/DAT to.eat the soup

'The mother made me eat the soup.'

$(\mathrm{ECM} / \mathrm{FI})$

\subsection{Prepositional Infinitival Construction}

The Prepositional Infinitival Construction (PIC, Raposo 1989) occurs only with perception verbs. Besides having prepositional infinitive (introduced by $a$ ), it can be either inflected or non-inflected. If the thematic subject of the embedded domain is a pronoun, it is an accusative pronoun adjacent to the perception verb. The complement of the perception verb is a unique constituent (shown by the some tests like Topicalization, pseudo-cleft and question-answer pair) and no lexical material can be inserted between the infinitive and the preposition. Even the sentential negation is not allowed (cf. (20c)). This construction has similarities with the dialectal one with gerund and may switch to it (cf. (20a) and (20d)).

(20) a. A mãe viu os filhos a sorrir/em.

The mother saw the children A to.smile. $\varnothing / 3 \mathrm{PL}$

'The mother saw the children smiling.'

b. A mãe viu-os a sorrir/em.

The mother saw-them.ACC A to.smile. $\varnothing / 3 P L$

'The mother saw them smiling.'

c. */?A mãe viu os filhos a não sorrir/em.

The mother saw the children A NOT to.smile. $\varnothing / 3 \mathrm{PL}$

'The mother saw the children not smiling.'

d. A mãe viu os filhos sorrindo.

The mother saw the children smiling.GER

'The mother saw the children smiling.' 


\section{Dialectal data}

In the previous sections, I described the causative and perception constructions with infinitival complements. Now I will show the dialectal data taken from CORDIALSIN corpus. Firstly I will concentrate on causative constructions and their geographical distribution and then I will focus on perception ones.

At this point it is important to underline that some examples are not easily classifiable. Firstly, there are cases, as it was said before, that are structurally ambiguous either between Inflected Infinite and ECM constructions or between ECM and Faire-Infinitive constructions. Secondly, if the thematic subject of the infinitival clause is not present it is impossible to verify its form and its position and, therefore, to identify the construction, like in the examples (21) and (22):

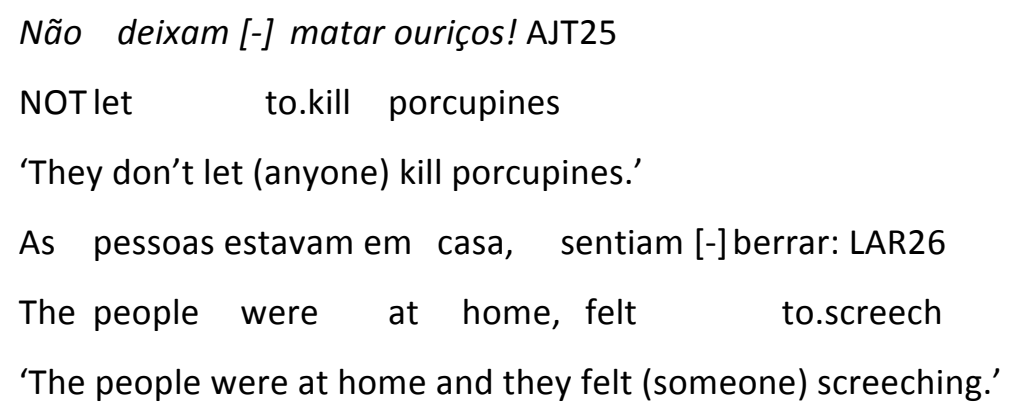

\subsection{Causative constructions}

Some aspects related to causative constructions, namely the form and the position of the called causee, in CORDIAL-SIN were already studied in Carrilho \& Pereira (2010). Throughout the corpus there are 469 occurrences of causative constructions with non-finite complements: 268 with deixar, 129 with mandar and 72 with fazer. 
Dialectologia. Special issue, $\mathbf{V}$ (2015), 53-80.

\subsubsection{Inflected Infinitive Construction}

With respect to this construction, we found only two non-ambiguous examples of this construction, both of them with fazer: ${ }^{4}$

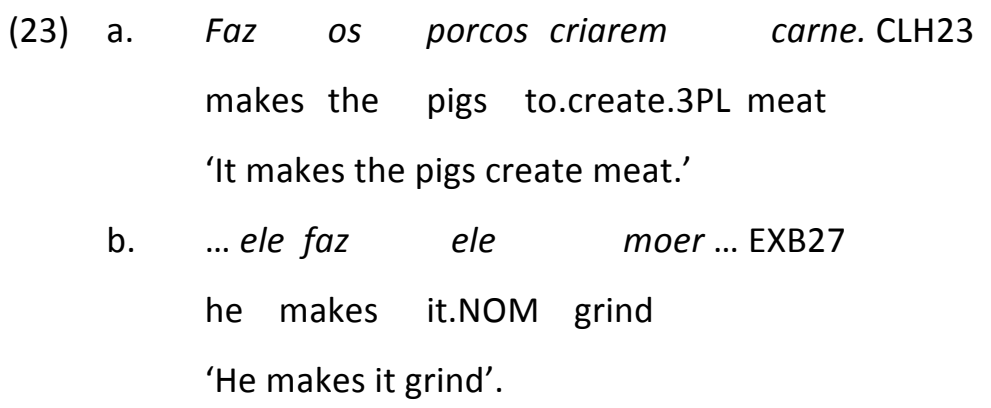

While in the first example the infinitive shows morphologically traces of person and number (criarem), sentence in b), since it is a third singular person, does not show any inflection. The fact that the embedded subject is a nominative pronoun argues for the Inflected Infinitive construction.

\subsubsection{Exceptional Case Marking Construction}

Regarding the ECM construction with causative verbs, there is only one nonambiguous example (cf. (24)), in spite of existing a lot of sentences that are ambiguous between this construction and the Inflected Infinitive construction.

$$
\begin{aligned}
& \text { Fazia-me acachapar-me, ao meio do caminho... EXB08 } \\
& \text { made-me to.lower-me at.the middle of.the way } \\
& \text { 'He made me lower in the middle of the way' }
\end{aligned}
$$

The fact that the inherent clitic occurs in the infinitival domain (acachapar-me) is an evidence to sort this phrase as an ECM structure. This is indeed a test presented by Gonçalves (1999) to distinguish between ECM construction and Faire-Infinitive

\footnotetext{
${ }^{4}$ Please, see the appendix to see, the number, name and abbreviation of the locations of CORDIAL-SIN.
} 
construction: the former allows anticausative and inherent clitics to occur in the infinitival domain whenever they are required by the verb. In fact, in the FaireInfinitive construction these clitics are not legitimated and therefore they are deleted.

In addition, there are several ambiguous examples between Inflected Infinitive and ECM construction, as the following example demonstrates:

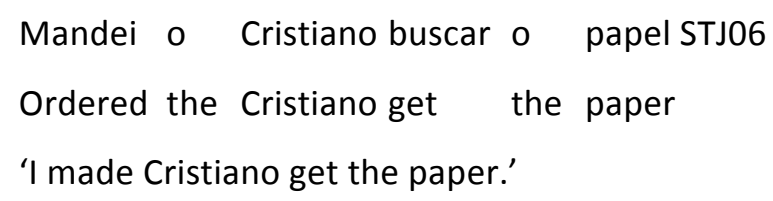

\subsubsection{Faire-Infinitive Construction}

This is the most frequent construction with causative verbs since there are 167 examples throughout the corpus.

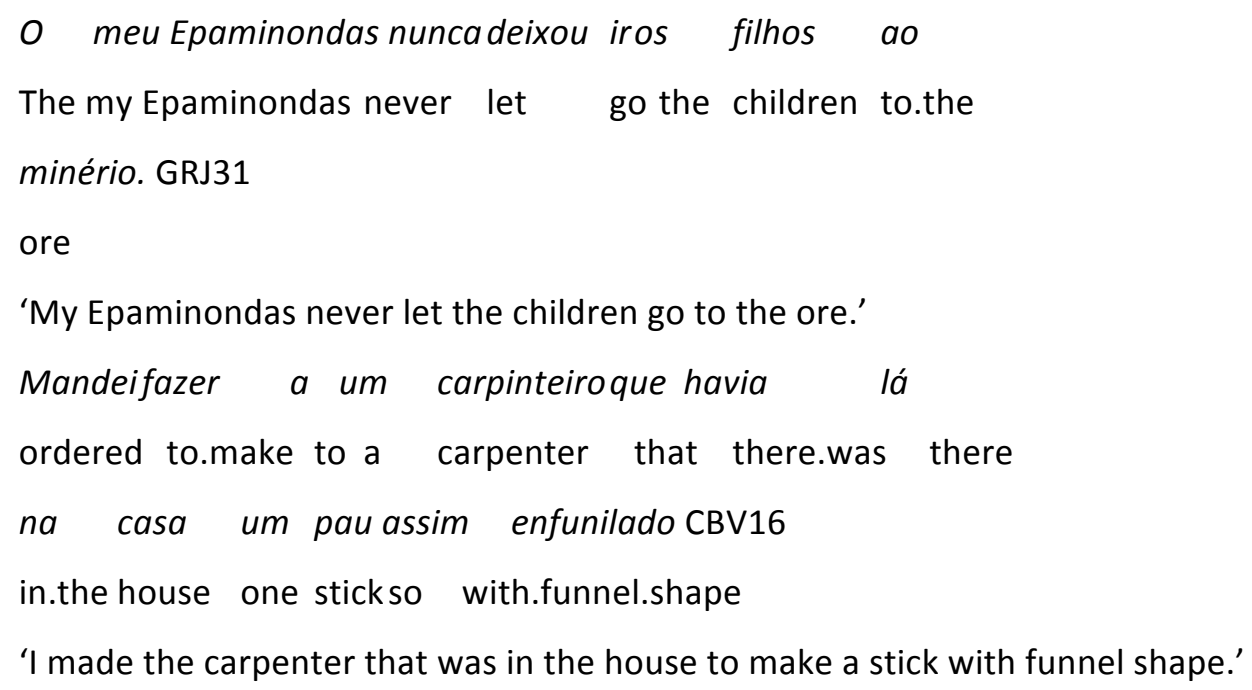

In (26) the infinitival verb is monoargumental and the causee is a noun phrase (os filhos). At the same time, in the example (27) the embedded verb is transitive and the causee is a prepositional phrase (a um carpinteiro).

As expected, some ambiguous examples (between ECM and Faire-Infinitive constructions) were found and are illustrated bellow: 
Dialectologia. Special issue, $\mathbf{V}$ (2015), 53-80.

ISSN: 2013-2247

O meu Epaminondas não a deixou mais ir. GRJ31

The myEpaminondas NOTher.ACC let more to.go

'My Epaminondas did not let her go again.'

(29)

"Esse senhor chega aí e manda-me

This gentleman arrives there and orders-me.ACC/DAT

cortar. MTV06

to.cut

'The gentleman gets there and makes me cut (it).'

In the first case, the infinitival verb is monoargumental and its subject is an accusative pronoun. In the example (29), the causee is a first plural pronoun that morphologically is ambiguous (it can be either accusative or dative).

\subsubsection{Causative Construction with Prepositional Infinitive}

CORDIAL-SIN's data also revealed a prepositional construction, illustrated in the following examples:

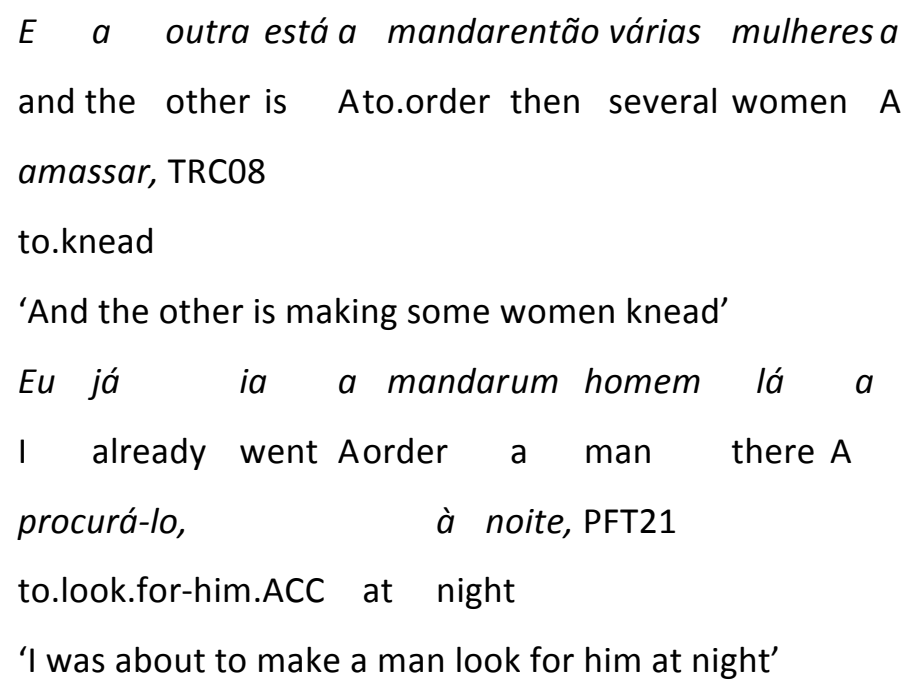

As it can be seen, in this construction the causee occurs between the causative and the infinitival clause and the infinitive has no inflection (cf. (30)), as in the ECM 
construction. The only difference between these constructions is that the former it is a prepositional infinitival construction. ${ }^{5}$

\subsection{Distribution of causative constructions}

Given these data, it is time to look to the geographical distribution of the different constructions. The mapping of CORDIAL-SIN causative structures shows that the most frequent construction in the corpus, i.e. the Faire-infinitive construction, is also, as expected, widespread throughout the country, as the Figure 1 shows.



Figure 1. Causative constructions - Faire-infinitive

The distribution of the alternative constructions is mapped in the Figure 2 , where we find the Inflected Infinitive construction, the ECM construction and the ambiguous cases.

\footnotetext{
${ }^{5}$ In fact, this construction is also found in ancient texts:

i) $E$ entam mandaram um mensageiro a chamar Josefes JAR103,2.42/ID and then ordered a messenger Ato.call Josefes 'And then they made a messenger call Josefes.'
} 
Dialectologia. Special issue, $\mathbf{V}$ (2015), 53-80.

ISSN: 2013-2247

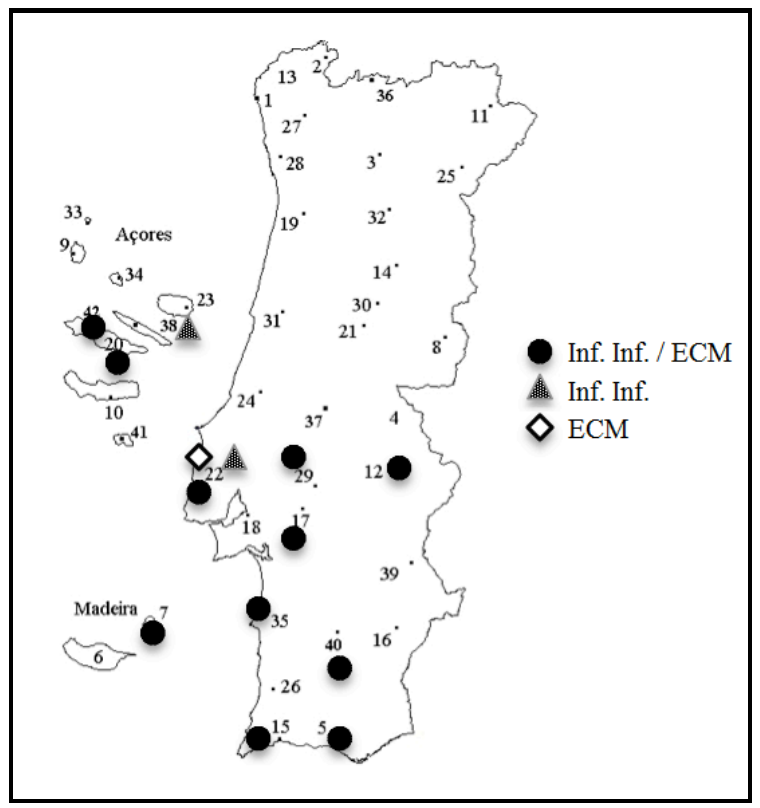

Figure 1. Causative constructions - alternatives to Faire-Infinitive

The ambiguous cases are not only more frequent but also more spread. While the ECM construction is found in one southern location, the Inflected Infinitive construction also is represented there and in an Azorean point. Significantly, none of these constructions occur in the North.

Moving to the distribution of the dialectal construction with prepositional infinitive, the Figure 3 shows that it is more concentrated in the Northern area. 




Figure 2. Causative construction - Prepositional Infinitival construction

In fact, this construction is presented in four locations: two of them in the North, one in Azores and another near Lisbon.

Summing up, according to CORDIAL-SIN data, the Faire-Infinitive construction is the most frequent with causative verbs and it is widespread throughout the whole country, except in Madeira. The constructions that are an alternative to this (i.e. the Inflected Infinitive construction, ECM construction and the ambiguous cases between them) are found in the islands and in the southern territory. On the contrary, the dialectal construction with prepositional infinitive occurs mainly in the North.

\subsection{Perception constructions}

In CORDIAL-SIN data, all the constructions are attested with the typical perception verbs (ouvir, sentir and ver). The most frequent is the PIC (52 sentences), followed by the Faire-Infinitive construction (42). Although there are several cases of ambiguity, both Inflected Infinitive and ECM constructions were found, respectively with 20 and 8 occurrences. 
Dialectologia. Special issue, $\mathbf{V}$ (2015), 53-80.

ISSN: 2013-2247

\subsubsection{Inflected Infinitive Construction}

The Inflected Infinitive construction is illustrated by the following examples:

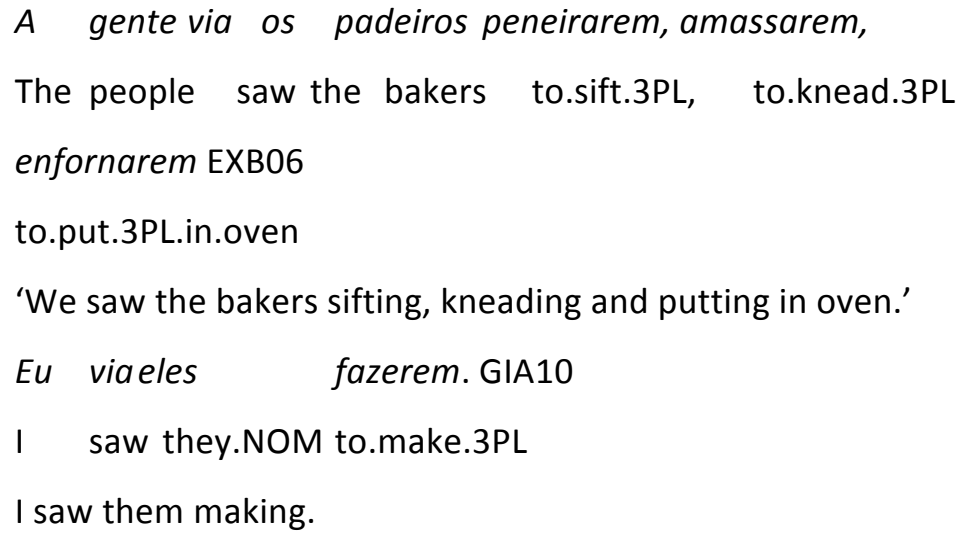

In these examples the infinitive exhibits inflection and the subject of the embedded domain receive nominative case, as it is expected.

\subsubsection{Exceptional Case Marking Construction}

In the corpus, the ECM construction with perception verbs is also represented, as the following examples shows.

$$
\begin{aligned}
& \text { Ah, mas eu ouvia os meus antigos dizer, PST18 } \\
& \text { Ah but I heard the myelders to.say } \\
& \text { 'Ah but I heard my elders saying.' } \\
& \text { Mas eu nuncavi mulheres lavrar aqui. CRV65 } \\
& \text { But I never saw women to.furrow here } \\
& \text { 'But I never saw women furrowing here.' }
\end{aligned}
$$

In these sentences, the thematic subject of the infinitival clause is between the two verbs. It is important to point out that it is a plural noun phrase and the infinitive does not have inflection. Hence (34) and (35) are unambiguous examples of ECM construction. 
In contrast, the next example is an ambiguous case:

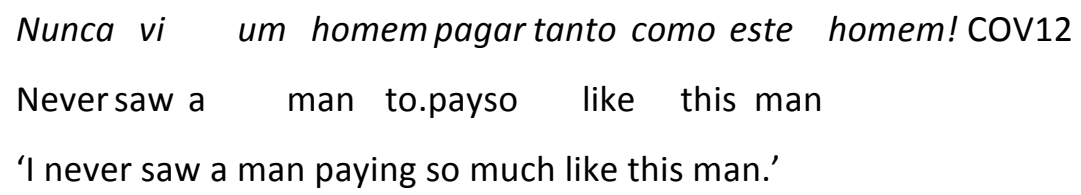

The fact that the infinitival subject is a singular noun phrase and the infinitive does not exhibit inflection argues for the ambiguity between Inflected Infinitive and ECM construction.

\subsubsection{Faire-Infinitive Construction}

We find this construction in the corpus, as the next examples with perception verbs illustrate:



While in the example (37) the infinitival verb is intransitive (i.e., it has only one argument), in (38) and (39) it is a transitive verb. In the example (40) there is a dative pronoun (and clitic doubling). This shows that this construction with perception verbs in some dialects is possible either with intransitive or transitive verbs, against what is claimed for standard EP (see Gonçalves 1999 and Silva 2012). 
Dialectologia. Special issue, $\mathbf{V}$ (2015), 53-80.

ISSN: 2013-2247

The example (41) bellow shows the ambiguity of some examples:

(41)
Ainda ontem $\quad 0$
vi aí passar, UNS36
Even yesterday him.ACC saw there go.past
'Even yesterday I saw him going past there'

\subsubsection{Prepositional Infinitival Constructions}

In what concerns PIC, some examples were found throughout the corpus:

(42)

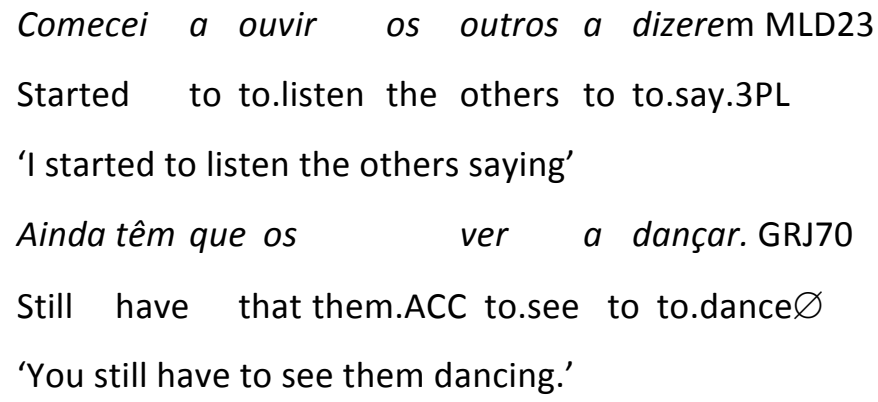

In the first example, the infinitive exhibits inflection in third plural person and its subject is a plural nominal phrase. At the same time, in (43) the subject is a plural accusative pronoun but the infinitive has no inflection, which is not that unusual, since the inflection is not obligatory.

\subsubsection{Personal Infinitival Non-Inflected Construction}

Besides the Faire-Infinitive construction with transitive verbs, CORDIAL-SIN also revealed other data that were not found in standard EP. One of these constructions is the Personal Infinitival Non-Inflected construction that is represented in the next examples:

$$
\begin{aligned}
& \text { Eu vi ela e ele } \quad \text { estar ali, STJ29 } \\
& \text { I saw she.NOMand he.NOM to.stand.Øthere } \\
& \text { 'I saw them standing there' }
\end{aligned}
$$




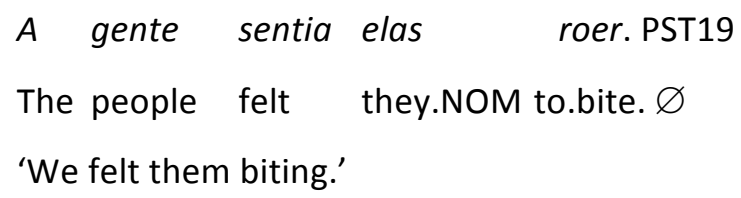

What is interesting about these phrases is the fact that the infinitival form has no inflection and the subject is a plural nominative pronoun (and not an accusative one, as it would be expected in standard EP for an ECM structure). Besides that, in this context we presuppose that the infinitive would show agreement with the pronoun but that does not happen, since there are no inflectional traces in the infinitival verb.

\subsubsection{Prepositional Infinitival Construction and Nominative Subject}

Another construction that was found in CORDIAL-SIN data is this construction with prepositional infinitive:



These sentences, which apparently have some similarities with the PIC (namely, the prepositional infinitive), are different because it is assigned nominative case to the infinitival subject. In the corpus there is no evidence for the presence of inflection in the infinitival form. Since all these subjects are singular forms, it is impossible to know whether the infinitive exhibits inflection (which is null for third singular person) or it is uninflected infinitive. 
Dialectologia. Special issue, $\mathbf{V}$ (2015), 53-80.

ISSN: 2013-2247

\subsection{Distribution of perception constructions}

In this section, I intend to show the distribution of perception constructions. The PIC is the most frequent in the corpus, as it was said before, and it is also the most spread with these verbs. The Figure 4 shows the distribution of this construction:

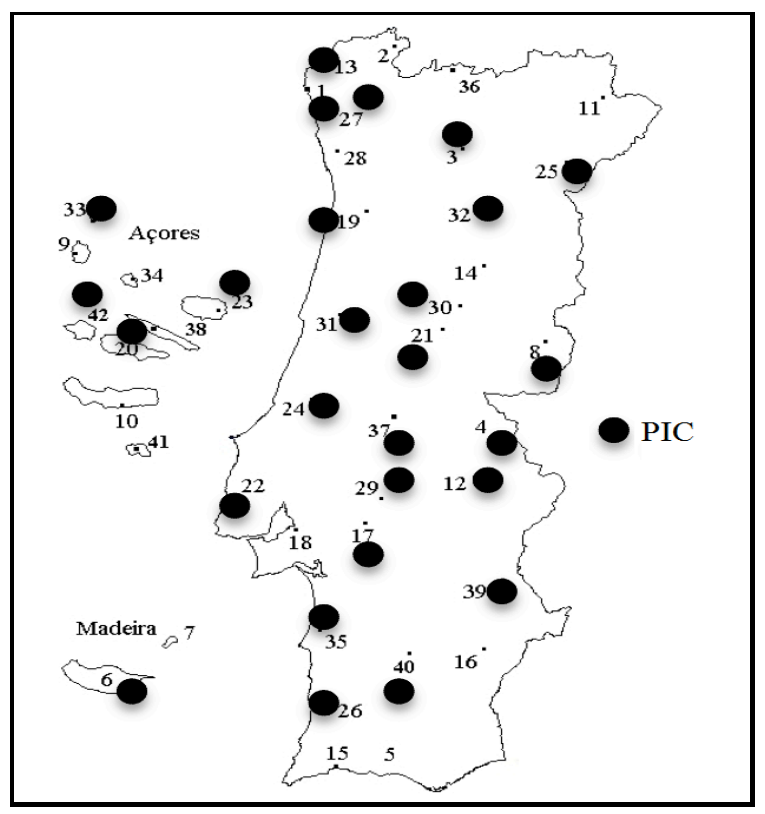

Figure 3. Perception Constructions - PIC

This construction occurs all over the country, including the insular territory (Azores and Madeira). According to the corpus data, the construction is not represented in Algarve as well as in the extreme north-eastern territory. There is no way to say that this absence is significant or it is just a consequence of the limited extension of the corpus.

Moving to the Faire-Infinitive construction, the Figure 5 maps its occurrence in CORDIAL-SIN corpus:

Considering only the unambiguous occurrences of this construction, we can see that it is very frequent and spread over the territory either with intransitive verbs or with transitive ones. The construction with transitive verbs is only found in continental territory. The absence of Faire-Infinitive in Madeira island seems significant since the scenario with causative constructions is very alike (see Figure 1 above). Furthermore, 
there are more locations where Faire-Infinitive occurs with causative verbs than with perception ones.

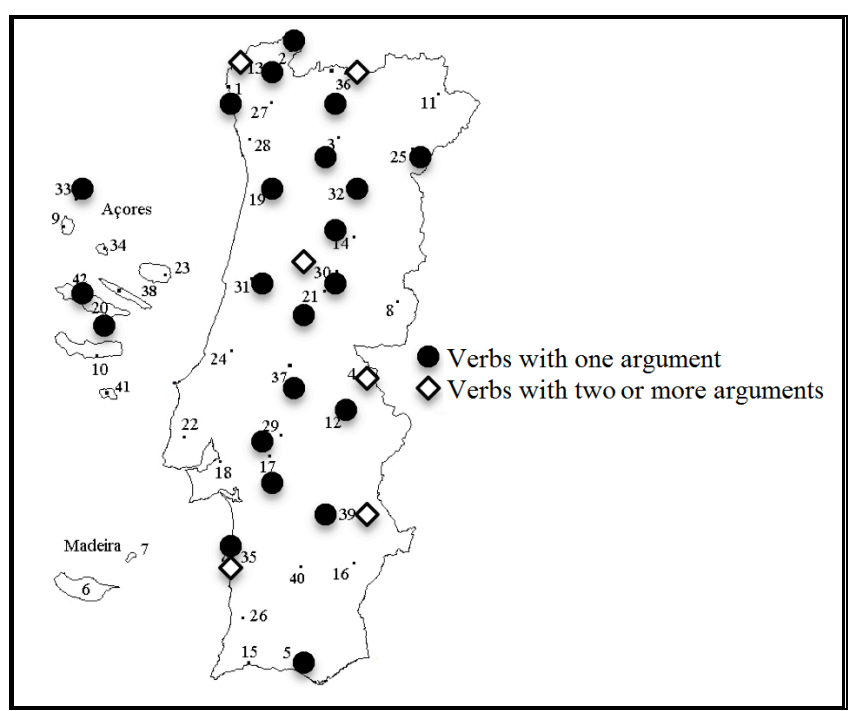

Figure 4. Perception Constructions - Faire-Infinitive

In the next Figure, the distribution of the alternative constructions to the FaireInfinitive is represented, that is to say: i) the cases of Inflected Infinitive (II), ii) the ECM and iii) the ambiguous cases of Inflected Infinitive and ECM constructions.

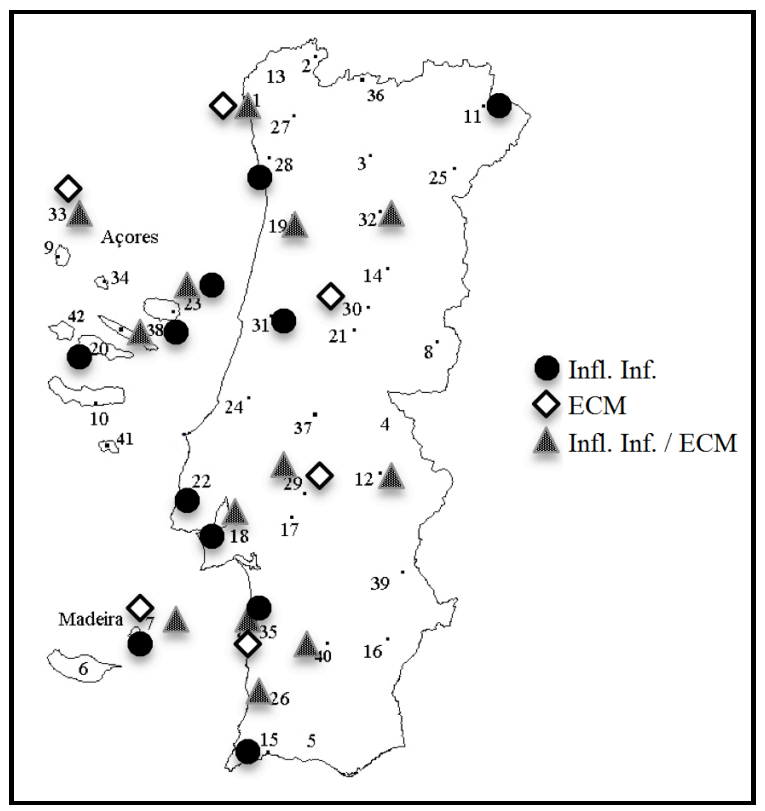

Figure 5. Perception Constructions - Alternatives to Faire-Infinitive 
These constructions, that do not form a complex predicate (contrary to FaireInfinitive constructions), are found in northern, southern and insular territory. However, they are not represented in some locations. In particular, they are not attested in the eastern border of the mainland and in two delimited regions, one in the center of the country, another in the North.

If we compare this Figure with the one with causative construction (see Figure 2 above), it is clear that the distribution of the Inflected Infinitive, the ECM and the ambiguous cases with perception verbs is more extended and it is not restricted to the southern dialects. This may be related to the fact that the Faire-Infinitive construction is not so spread with these verbs and the former are, in fact, an alternative to the latter.

Finally, in Figure 7 is mapped the distribution of the dialectal constructions found with perception verbs.

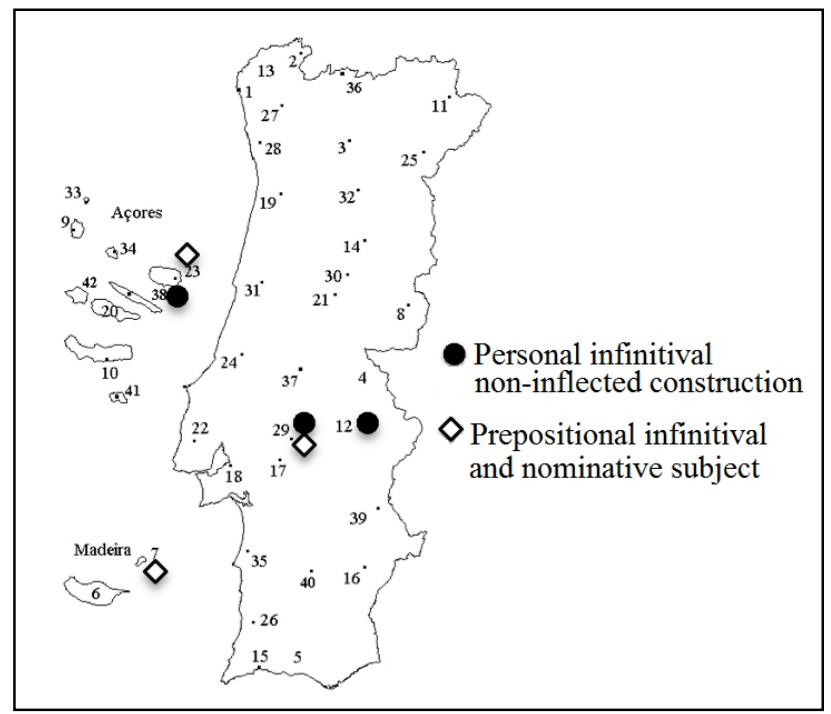

Figure 6. Perception constructions - the dialectal perception constructions

These dialectal constructions have a similar distribution: both occur in Ribatejo and Azores. Notably both constructions share the fact that an accusative pronoun is expected in standard variety.

In short, all the perception constructions found in standard EP occur in CORDIALSIN data. Furthermore new constructions arise and, for instance, the structure with Faire-Infinitive has different characteristics. 


\section{Concluding remarks}

The data presented previously lead us to the conclusion that, in what concerns the Inflected Infinitive, the ECM and the Faire-Infinitive constructions, the causative verbs and the perception ones show a similar behaviour. In fact, the differences described for standard EP for Faire-Infinitive construction do not apply to EP dialects nor to Old Portuguese (cf. Pereira 2015). Data from other periods of Portuguese need to be inspected in order to see when the restrictions found in EP emerged. Additionally, in each group of verbs new constructions were revealed.

With respect to the spatial distribution, as has been noted, the PIC is the most frequent and widespread construction in the whole territory with the perception verbs, followed by the Faire-Infinitive, that does not occur in Madeira islands. The Inflected Infinitive and the ECM constructions are more common with perception than with causative verbs. With these ones, the Faire-Infinitive construction is the most usual and it can be found everywhere except in Madeira. There are few unambiguous cases of Inflected Infinitive and ECM constructions. Concerning the ECM construction, it seems that some EP dialects (in the North) lack this structure. For this reason, the approaching of these dialects to other Romance languages should be considered.

\section{References}

BossaglIA, Giulia (2013) "Inflected/Non-inflected Infinitive Alternation in Causative and Perception Constructions of Contemporary European Portuguese: A Corpus-based Study", Procedia - Social and Behavioral Sciences 95, 220-230.

Carrilho, Ernestina \& Sandra Pereira (2010) "Causees in European Portuguese Dialects: some Observations on the Properties and the Position of the Causee in Causative Constructions in CORDIAL-SIN", Wedisyn's First Workshop on Syntactic Variation, IKER, Bayonne. [http://www.clul.ul.pt/files/ernestina_carrilho/CarrilhoPereira2010_HO.pdf (12/09/2012)].

DUARTE, Inês \& Anabela GonçALVES (2002) "Construções de Subordinação Funcionalmente Defectivas: o Caso das Construções Perceptivas em Português Europeu e Português 
Dialectologia. Special issue, $\mathbf{V}$ (2015), 53-80.

ISSN: 2013-2247

Brasileiro", in Anabela Gonçalves \& Clara Nunes Correia (orgs.), Actas do XVII Encontro Nacional da Associação Portuguesa de Linguística, Lisboa: APL/Colibri, 161-173.

GonçALVES, Anabela (1999) Predicados Complexos Verbais em Contextos de Infinitivo não Preposicionado do Português Europeu, PhD Disssertation, Universidade Lisboa.

GonçALVES, Anabela (2001) "Predicados Complexos com Verbos Causativos e Perceptivos no Português Europeu", in Anabela Gonçalves \& Clara Nunes Correia (orgs.), Actas do XVI Encontro Nacional da Associação Portuguesa de Linguística, Lisboa: APL/Colibri, 227239.

GonçAlves, Anabela \& Inês DuARTE (2001) “Construções Causativas em Português Europeu e em Português Brasileiro", in Anabela Gonçalves \& Clara Nunes Correia (orgs.), Actas do XVI Encontro Nacional da Associação Portuguesa de Linguística. Lisboa: APL/Colibri, 657671.

GUASTI, M.T. (2005) "Analytic causatives", in M. Everaert \& H. van Riemsdijk (eds.), Blackwell Companion to Syntax, vol. I, Oxford: Blackwell, 142-172.

HoRnsteIn, Norbert, Ana Maria MARTINS \& Jairo Nunes (2006) "Infinitival Complements of Perception and Causative Verbs: a Case Study on Agreement and Intervention Effects in English and European Portuguese", in Nina Kazanina, Utako Minai, Philip J. Monahan \& Heather L. Taylor (eds.), University of Maryland Working Papers in Linguistics, 14, 81110. [http://www.clul.ul.pt/files/ana_maria_martins/MartinsInfinitivalComplements.pdf $(12 / 09 / 2012)]$

HORnSteIN, Norbert, Ana Maria MARTINS \& Jairo NUNES (2008) “Perception and Causative Structures in English and European Portuguese: $\phi$-feature Agreement and the Distribution of Bare and Prepositional Infinitives", Syntax, 11/2, 205-229.

KAYNE, R. (1975) French Syntax: The Transformational Cycle, Cambridge, Mass: MIT Press.

MARTINS, A. M. (forthcoming) "Infinitival complements of causative/perception verbs in a diachronic prespective", in Anabela Gonçalves \& Ana Lúcia Santos (eds.), Complement Clauses in Portuguese: Syntax and Acquisition, Amsterdam/Philadelphia: John Benjamins.

MARTINS, A. M. (coord.) [2000- ] 2010. CORDIAL-SIN: Corpus Dialectal para o Estudo da Sintaxe/Syntax-oriented Corpus of Portuguese Dialects, Lisboa, Centro de Linguística da Universidade de Lisboa. [http://www.clul.ul.pt/en/resources/411-cordial-corpus].

PereIRA, Sandra (2012) Protótipo de um Glossário dos Dialetos Portugueses com Informação Sintática, PhD Dissertation, University of Lisbon. 
Pereira, Sandra (2015) "Construções percetivas e ordem de palavras num texto medieval", Estudos de lingüista galega, 7, 95-108. [http://dx.doi.org/10.15304/elg.7.2331].

RAPOSO, Eduardo (1989) "Prepositional Infinitival Constructions in European Portuguese", in O. Jaeggli \& K. Safir (eds.), The Null Subject Parameter, Dordrecht: Kluwer Academic Publishers.

SILVA, Augusto da Silva (2012) "Stages of grammaticalization of causative verbs and constructions in Portuguese, Spanish, French and Italian", Folia Linguistica, 46: 2, 513 552. 